\title{
Taurine Reduces Heat Stress by Regulating the Expression of Heat Shock Proteins in Broilers Exposed to Chronic Heat
}

\section{-Author(s)}

\section{Belal SA' \\ Kang DR' \\ Cho ESR' \\ Park $\mathrm{GH}^{\prime}$ \\ Shim KS'}

Department of Animal Biotechnology, Chonbuk National University, Jeonju-si 54896, Republic of Korea.

\section{Mail Address}

Corresponding author e-mail address Kwan Seob Shim

Department of Animal Biotechnology, Chonbuk National University, Jeonju-si

54896, Republic of Korea.

Phone: +82-63-270-2609

Email: ksshim@jbnu.ac.kr

\section{-Keywords}

Broiler, taurine, heat stress, heat shock protein, gene and protein expression.

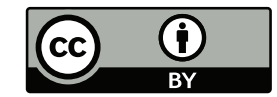

Submitted: 17/December/2017 Approved: 21/February/2018

\section{ABSTRACT}

The aim of the current study was to investigate the effects of taurine on heat stress by evaluating them RNA and protein expressions of HSP90, 70 and 60in Ross broilers. Birds were distributed in a control group (CO) reared at $24^{\circ} \mathrm{C}$, a heat-stress group (HS) maintained at $34^{\circ} \mathrm{C}$ (weeks 3-5) and not supplemented with taurine, and a heatstress group (HST) maintained at $34^{\circ} \mathrm{C}$ (weeks 3-5) and supplemented with $0.1 \%$ taurine from 2 weeks of age. The final body weight was significantly higher in the HST group than in the HS group $(p<0.05)$. The mRNA expression of all three genes in the liver and of HSP9O in the muscle were significantly lower in the HST than in the HS group $(p<0.05)$. In the liver, the expression of HSP70 and HSP60 proteins was significantly higher in the HS group compared with the CO and HST groups ( $p<0.05)$, while HSP90 expression was not different $(p>0.05)$. In the muscle, HSP70 expression was significantly lower in the HST group than in the CO and HS groups and HSP60 expression was dramatically decreased in HS group, whereas no differences in HSP90 expression were detected among groups. In conclusion, the broilers exposed to heat stress and supplemented with taurine showed lower expressions of heat shock genes and proteins both in the liver and muscle tissues, indicating that taurine supplementation improved broiler thermotolerance.

\section{INTRODUCTION}

Due to global warming, there is an increasing interest in the research of heat stress and its impact on livestock production. Thermal conditioning has been shown to improve the heat tolerance of broilers submitted to heat stress (Vinoth et al., 2015). Temperature is one of the main factors that negatively affect the production performance and has stronger effects on poultry compared with other livestock species. Chickens have no sweat glands and, due to their fast metabolic rates and high body temperature, are very sensitive to high ambient temperatures. Birds can only tolerate a very narrow temperature range, of $18-24^{\circ} \mathrm{C}$ (Rajkumar et al., 2011). Heat stress causes several physiological and metabolic changes in chickens, which have negative effects on body weight gain, feed efficiency, and serum triglyceride and uric acid levels (Deyhim et al., 1995), eggshell quality and livability (Quinteiro-Filho et al., 2010; Mashaly et al., 2004), in addition of increasing production costs (Rajkumar et al., 2011).

Some dietary supplements may enhance physiological mechanisms that allow chickens to better resist heat stress. Yahav et al. (1997) suggest that the mechanisms enabling better survival of broiler involves those that reduced hyperthermia and protected the body tissues from heat stress. Some researchers found that the dietary supplementation 
of taurine, betaine, vitamin C, and vitamin Emay improve the growth performance and livability of birds under heat-stress situations (Ipek et al., 2007; Shim et al., 2006; Zulkifli et al., 2004). Zulkifli et al. (2007) also reported that a palm oil diet reduced the body temperature and mortality rate of chickens during heat exposure.

Heat shock proteins (HSPs) are highly conserved protein families synthesized in response to physical or biological stressors, including heat exposure (Staib et al., 2007). It is well documented that one of the most important HSP functions is the protection of the body from the toxic effects of heating (Arrigo, 2000). HSPs may play important roles in protein folding or unfolding and translocation (Zügel \& Kaufmann, 1999), in protein (dis)assembly (Bukau et al., 2000), as well as in damaged protein refolding (Maloyan et al., 1999). HSPs are broadly classified into six distinct families according to their molecular weights, from 10 to 150 kDA (Benjamin \& Mc Millan, 1998) and their sizes: small HSPs, HSP40, HSP60, HSP70, HSP90, and HSP110 (Habich \& Burkart, 2007). The degree of stimulated heat tolerance is related to HSP expressions (Krebs and Bettencourt, 1999); 70 kDA appears to be closely associated with HSP heat tolerance (King et al., 2002; Wang \& Edens, 1998). HSP70 is the earliest responsive gene (Morimoto, 1998).

Taurine, a $\beta$-aminoethanesulfonic acid, is derived from free amino acids and found in large quantities in almost all animal tissues, and presents colorless and odorless properties (Shim et al., 2006). It is a chemically-simple compound but has profound effects on cells and is an essential nutrient for many mammals (Schaffer et al., 2010). Taurine has been shown to play a role in bile-acid binding (Ito et al., 2004), intracellular osmotic pressure control (Schaffer et al., 2010), antioxidant protection (Kocak-Toker et al., 2005), and in alleviating heat stress (Shim et al., 2006). However, to the best of our knowledge, there are no studies on the effects of dietary taurine supplementation on heatshock proteins and gene expressions in the liver and muscles of broilers submitted to heat stress. Therefore, this study aimed at investigating the effect of dietary taurine supplementation on heat-shock proteins and gene expressions of broiler under heat stress.

\section{MATERIALS AND METHODS}

\section{Birds and experimental procedures}

All experiments were undertaken in accordance with the guidelines of the Care and Use of Experimental
Animals, Chonbuk National University, Republic of Korea. The study protocol was approved by the Animal Care and Use Committee of Chonbuk National University. Maximum care was taken to minimize suffering of the birds.

One-hundred twenty one-day-old Ross broilers were obtained from a commercial hatchery (Dongwoo, Inc., Kimhae, Republic of Korea). The treatments consisted of a control group (CO), which birds were reared at $24^{\circ} \mathrm{Cand}$ not supplemented with taurine; a heatstressed group (HS), which birds were maintained at $34^{\circ} \mathrm{C}$ from 3 to 5 weeks of age and not supplemented with taurine; and a heat-stressed group(HST), which birds were reared at $34^{\circ} \mathrm{C}$ from 3 to 5 weeks of age and were supplemented with $0.1 \%$ taurine in the drinking water from 2 weeks of age. The experimental scheme is shown in Figure 1.

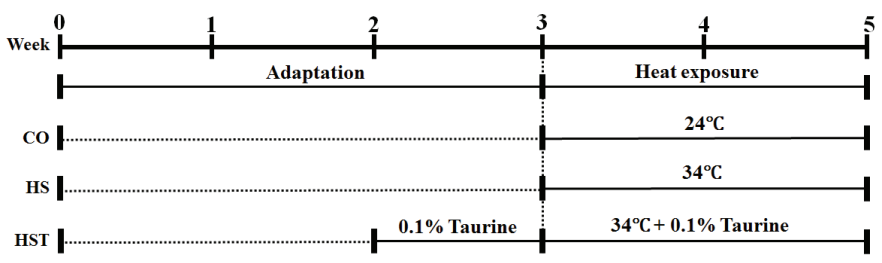

Figure 1 - Experimental schedule, including the heat exposure and taurine supplementation periods.

The experiment was conducted at the experimental farm of Chonbuk National University, Jeonju, Republic of Korea. Broilers were reared in stainless steel cages equipped with nipple drinkers and hanging feeders at 10 birds per cage. Control group (CO) and heatstressed groups (HS and HST) were reared in separate room to apply the temperatures of $24^{\circ} \mathrm{C}$ and $34{ }^{\circ} \mathrm{C}$ respectively.

The environmental temperature on the day of placement was $34^{\circ} \mathrm{C}$ and was gradually decreased to $24^{\circ} \mathrm{C}$ until day 21 , when birds were allocated to the three experimental groups, with four replicates of 10 birds each. The HST group received $0.1 \%$ taurine in drinking water from the second week on for adaptation to taurine. Heat exposure started on the third week, when the environmental temperature was maintained of $34^{\circ} \mathrm{C}$ for the $\mathrm{HS}$ and HST groups. Control birds were kept at $24^{\circ} \mathrm{C}$ during the experimental period.

Broilers were fed starter ( 1 to 21 days of age as mash) and grower (22 to 35 days of age as crumble) commercial feeds purchased from Purina (Cargill Agri Purina Inc., Seongam City, Republic of Korea). The chicks received a commercial basal diet containing $19 \% \mathrm{CP}$ and 3,000 kcal ME/kg. Feed and water were supplied ad libitum throughout the experimental period. 
During the whole experimental period, the lights were kept on all day and the humidity was maintained on an average of $60 \%$ respectively. At the end of experimental period (day 35), the birds were weighed after 12-h fasting, sacrificed and liver and muscle samples were collected for analyses.

\section{Sample collection}

At the end of the experimental period, 10 birds per treatment were randomly selected and sacrificed by decapitation. Carcasses were manually eviscerated and liver and breast muscles were dissected, collected, and aseptically placed into $2 \mathrm{~mL}$ tubes. The tubes were frozen in liquid nitrogen and stored at $-70^{\circ} \mathrm{C}$ until analyses.

\section{RNA isolation and CDNA synthesis}

Total RNA was extracted from liver and muscle tissues by using TRIzol Reagents (Invitrogen, NY, USA), according to the manufacturer's instructions. Total RNA was quantified by nano drop (ThermoFisher Scientific, USA) at $260 \mathrm{~nm} / 280 \mathrm{~nm}$ absorbance. The quality of total RNA was assessed by using Experion ${ }^{\mathrm{TM}}$ Automated Electrophoresis System (BIO-RAD, Hercules, CA, USA) with RNA chip kits (Experion ${ }^{\text {TM }}$ RNA StdSens Reagents, \#700-7259, BIO-RAD) and good-quality RNA samples $(1 \mu \mathrm{g})$ were selected for further reverse transcription (Figure 1) into $\mathrm{CDNA}$, using iscript ${ }^{\mathrm{TM}} \mathrm{CDNA}$ Synthesis kit (BIO-RAD). The reverse transcription was processed at
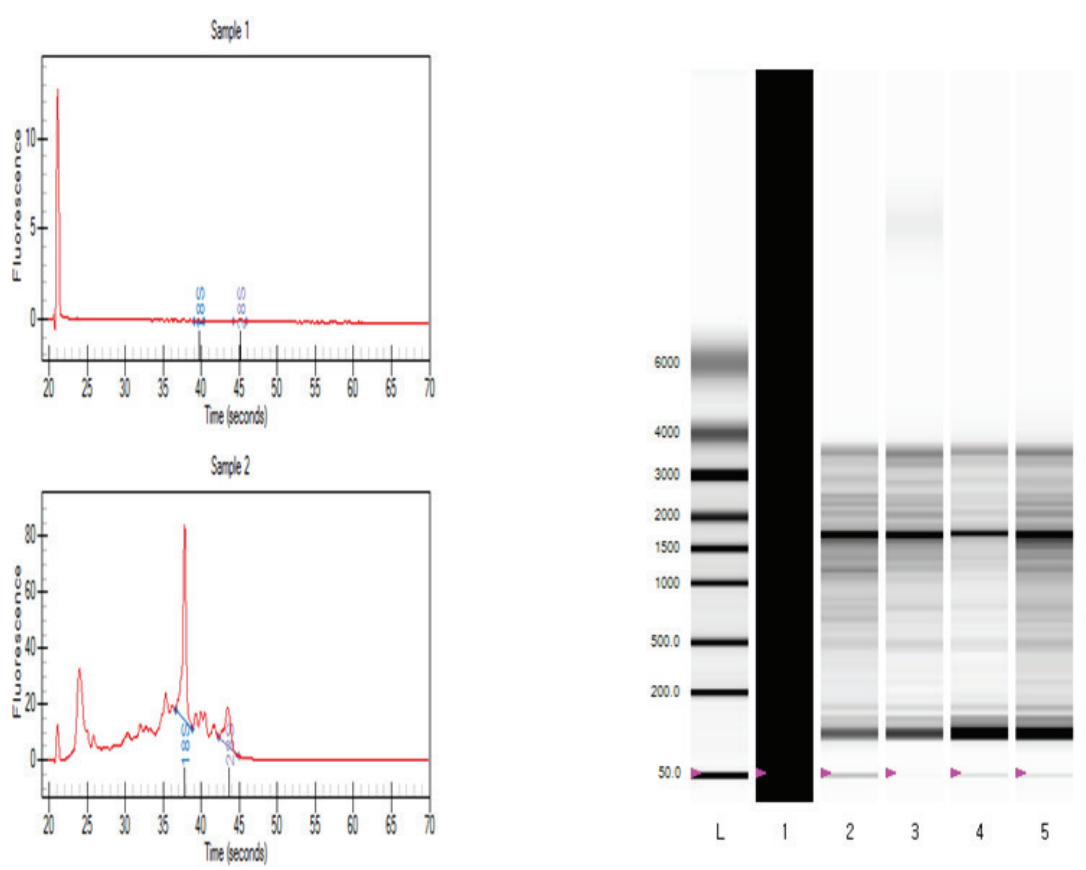

Figure 2 - RNA integrity check. The $18 \mathrm{~S}$ and $28 \mathrm{~S}$ peaks are clearly visible in sample 2, but not in sample 1. In gel electrophoresis, Lane 1 shows totally degraded RNA, while in Lanes 2-5, RNA is intact, with clear $18 \mathrm{~S}$ and $28 \mathrm{~S}$ rRNA bands. $25^{\circ} \mathrm{C}$ for $18 \mathrm{~s}$, followed by 11 cycles at $48^{\circ} \mathrm{C}$ for $4 \mathrm{~min}$, and the enzyme reaction was inhibited at $55^{\circ} \mathrm{C}$ for $18 \mathrm{~s}$.

\section{Quantitative real-time polymerase chain reaction (qRT-PCR)}

Real-time PCR was performed using SsoFast ${ }^{\mathrm{TM}}$ EvaGreen ${ }^{\circledR}$ Supermix (BIO-RAD, USA) andCFX96 ${ }^{\mathrm{TM}}$ Real-Time PCR detection System (BIO-RAD). The cDNA of each gene was amplified and the reaction was carried out according to the manufacturer's instructions (BIO-RAD). Briefly, PCR was conducted in a $20 \mu \mathrm{L}$ total reaction volume containing $100 \mathrm{ng}$ cDNA, $10 \mu \mathrm{L}$ SsoFast ${ }^{\mathrm{TM}}$ EvaGreen $^{\circledR}$ Supermix, and $1 \mu \mathrm{L}$ of $10 \mathrm{pM}$ primers. The first-strand cDNAs were used as a template to amplify gene-specific primers for HSP90, HSP70, HSP60, and the housekeeping gene GAPDH (Glyceraldehyde-3-phosphate dehydrogenase). The thermal cycling parameters were as follows: $95^{\circ} \mathrm{C}$ for $2 \mathrm{~min}$, followed by 40 cycles at $95^{\circ} \mathrm{C}$ for $5 \mathrm{~s}, 59^{\circ} \mathrm{C}$ for 5 $\mathrm{s}$, and $65^{\circ} \mathrm{C}$ for $5 \mathrm{~s}$. The expressions of the target genes were normalized with GAPDH. The primer sequences of the gene fragments are presented in Table 1.

\section{Western blot analysis}

Chicken livers and muscles were homogenized in 1 $\mathrm{mL}$ RIPA buffer (50 mM Tris, $150 \mathrm{mM} \mathrm{NaCl}, 0.1 \%$ SDS, $0.5 \%$ deoxy cholic acid, $1 \%$ triton $\mathrm{X}-100 . \mathrm{pH} 7.5$ ) and centrifuged for $20 \mathrm{~min}$ at $12,000 \mathrm{rpm}$. The supernatant was stored at $-20^{\circ} \mathrm{C}$. Before western blotting, sample proteins were quantified using $D C$ Protein assay kit (BIO-RAD, USA) following the manual's instructions, according to which BSA functions as the standard, and samples were measured at 750nm. Equal amounts of protein samples were loaded on $12 \%$ SDSPAGE gels to separate proteins according to molecular weight and then transferred to PVDF membranes (Immuno-Blot PVDF membrane Roll, BIO-RAD, USA) with a Semi-Dry Electrophoretic Transfer Cell (BIORAD Laboratories, USA). Membranes were blocked for $3 \mathrm{~h}$ at room temperature in 5\% skimmed milk in TTBS $(20 \mathrm{mM}$ Tris, 137 $\mathrm{mM} \mathrm{NaCl}, 5 \mathrm{mM} \mathrm{KCl}, 0.05 \%$ Tween-20 $(\mathrm{v} / \mathrm{v}), \mathrm{pH}$ 7.4). After blocking, membranes were washed three times in TTBS for 5 min at room temperature and incubated with HSP90, HSP70, HSP60, and $\beta$-actin in $3 \%$ skimmed milk as primary antibodies overnight at $4^{\circ} \mathrm{C}$. The membranes were again washed three times for 10 min with 
Table 1 - Primer sequences used for gene fragments.

\begin{tabular}{llll}
\hline Primer & Accession number & Sequence $\left(5^{\prime}-3^{\prime}\right)$ & Product size (bp) \\
\hline HSP90 & NM_206959.1 & F- GCATTCTCAGTTCATTGGCTACC & 122 \\
HSP70 & R- CTGTCTTCTCCTCCTTCTCCTCT & 95 \\
HSP60 & NM_001012916.1 & R-ATGAGCACAAGCAGAAAGAG & 116 \\
GAPDH & NM_204305.1 & F-AGAAGAAGGACAGAGTTACC & 130 \\
\hline
\end{tabular}

HSP90: Heat shock protein 90, HSP70: Heat shock protein 70, HSP60: Heat shock protein 60, GAPDH: Glyceraldehyde-3-phosphate dehydrogenase.

TTBS and incubated with rabbit anti-rat IgG-HRPgo at anti-rabbit IgG-HRP, as well as goat anti-mouse IgG-HRP as secondary antibodies for $1.5 \mathrm{~h}$ at room temperature. After incubation, membranes were washed TTBS three times for 10 min for a third time at room temperature, incubated in $6.30 \mathrm{~mL}$ of a HRP colorimetric reagent (BIO-RAD, USA) for $1 \mathrm{~h}$ at room temperature, and washed with DW. The membranes were scanned using a Bio-5000 plus Microtek (BIORAD, USA) and the band intensities were analyzed by the Quantity One Software (BIO-RAD Laboratories, USA). The protein band intensity value was normalized by the intensity of the $\beta$-actin band.

\section{Statistical analysis}

The study data were analyzed by analysis of variance using the software SAS (SAS 9.1,USA). Duncan's multiple range test was applied to compare the means. The values were expressed as the mean \pm SE (standard error). Values were considered significantly different at $p<0.05$.

\section{RESULTS}

\section{Effect of heat stress on body and liver weights}

Body and liver weight results are shown in Table 2. At the end of the study, final body weight was significantly higher in the HST group than in the HS group ( $p<0.05)$. Liver weight was higher in $\mathrm{CO}$ than the other groups and the liver/body weight ratios were significantly lower in the HST group compared with the $\mathrm{CO}$ and HS groups $(p<0.05)$.

\section{Effect of heat stress on gene expression}

The liver mRNA expression of all the three genes in the liver were significantly higher in the HS group and lower in the HST than in the CO group $(p<0.05)$. However, muscle HSP70 and 60 mRNA expressions were not significantly different among treatments. The muscle mRNA expression of HSP90 was significantly lower in the HST group compared with the HS and CO groups (Figure 3A and 3B).

A
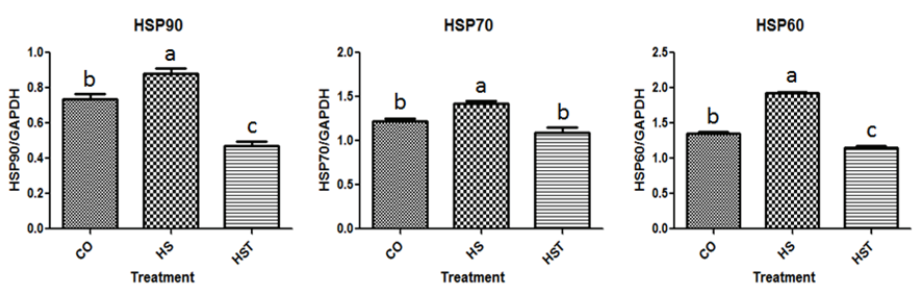

B
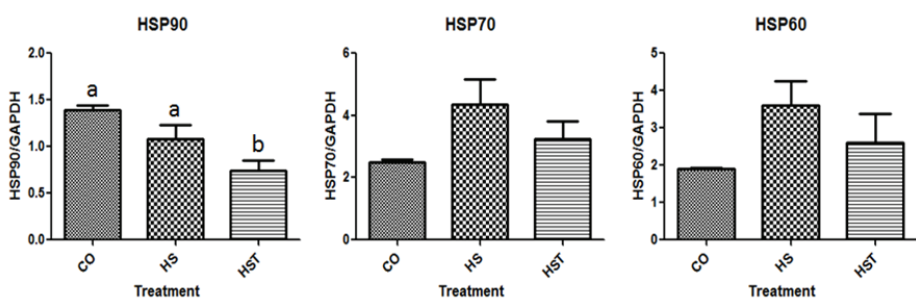

Figure 3 - Heat shock protein (HSP) gene expression. A: liver tissue, B: muscle tissue. Values are expressed as mean \pm SE from individual tissue samples $(n=6)$. Means with different superscripts indicate statistically significant differences $(p<0.05)$.

\section{Effect of heat stress on protein expression}

In the liver, the protein expression of HSP70 and HSP6O was significantly higher in the HS group compared with the CO and HST groups $(p<0.05)$ and

Table 2 - Effect of taurine on final body weight, liver weight, and liver/body weight ratios of broilers.

\begin{tabular}{lccc}
\hline Items & CO & HS & HST \\
\hline Final body weight (g) & $2336.50 \pm 31.22^{\mathrm{a}}$ & $1881.70 \pm 50.08^{\mathrm{c}}$ & $2067.90 \pm 37.56^{\mathrm{b}}$ \\
Liver weight (g) & $63.83 \pm 9.67^{\mathrm{a}}$ & $50.98 \pm 7.81^{\mathrm{b}}$ & $49.18 \pm 5.05^{\mathrm{b}}$ \\
Liver weight/body weight (\%) & $2.73 \pm 0.10^{\mathrm{a}}$ & $2.71 \pm 0.10^{\mathrm{a}}$ & $2.38 \pm 0.06^{\mathrm{b}}$ \\
\hline
\end{tabular}

Mean values are presented as means \pm SE. Values in same row with different superscript letters are significantly different $(p<0.05)$.

CO: Control group reared at $24^{\circ} \mathrm{C}$ and not supplemented with taurine; HS:heat-stressed group maintained at $34^{\circ} \mathrm{C}$ and not supplemented with taurine; HST:heat-stressed group maintained at $34^{\circ} \mathrm{C}$ and supplemented with $0.1 \%$ taurine. 
as lower in the HST group than the HS group, while HSP90 was similar among groups ( $p>0.05$ )(Figure $4 A)$. In the muscle, HSP70 expression was significantly lower in the HST group compared with the CO and HS groups, whereas HSP90 expression was not different among the groups (Figure 4B). However, HSP60 muscle expression was dramatically lower in the HS group with the HST group $(p<0.05)$.
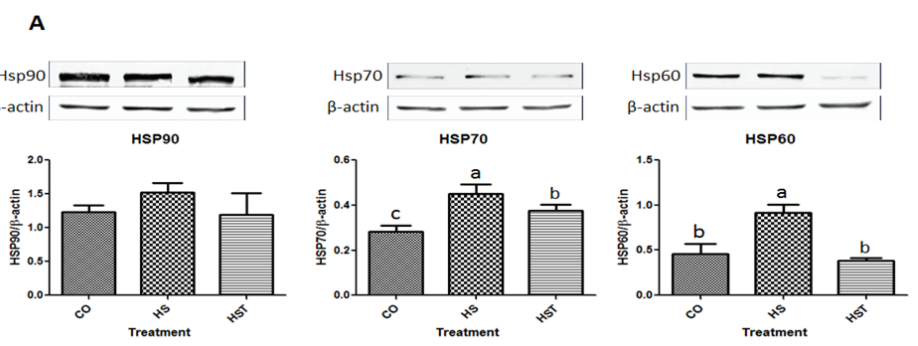

B
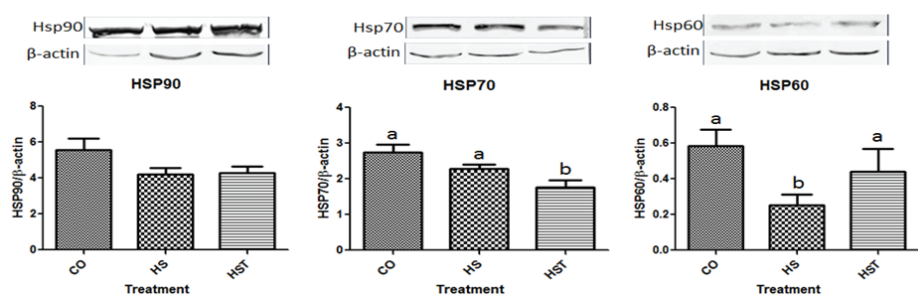

Figure 4 - Western blot of heat shock protein (HSP) expression. A: liver tissue, B: muscle tissue. Values are expressed as mean \pm SE from individual tissue samples $(n=6)$. Means with different superscripts differ significantly $(p<0.05)$.

\section{DISCUSSION}

Final body weight was significantly lower in the HS group than in the CO group $(p<0.05)$, as previously found by Sohail et al. (2012) and Deeb \& Cahaner (2002), who reported $10 \%$ body weight loss in broiler chickens exposed to chronic heat stress. The body weight of the taurine-supplemented group (HST) submitted to heat stress was higher (9.0\%) than that of the HS group $(p<0.05)$, in agreement with Shim et al. (2006), who determined markedly higher body weight gain of broilers exposed to chronic heat stress of $34^{\circ} \mathrm{C}$ and fed dietary taurine compared with those not fed taurine. Similar to final body weight, significantly liver weight reduction was observed in broilers submitted to heat stress. These findings are consistent with those of Felver-Gant et al. (2012), who reported low liver weight in laying hens exposed to chronic heat stress. Higher liver weights were determined in the CO group than HS and HST groups; however, Shim et al. (2006) demonstrated that $0.8 \%$ taurine added to chickens under chronic heat stress had a high liver weight. Significantly lower liver/body weight ratios were determined in the HST group during the entire period of heat stress exposure than in the other groups. Plavnik \& Yahav (1998) previously observed that heat stress reduced relative liver weight due to decreased metabolic needs.

To our knowledge, this is the first study on the HSP gene and protein expressions in the liver and muscle tissues of broilers receiving taurine when exposed to heat stress. In general, all cells respond to increased temperature by rapid gene transcription and subsequent mRNA translation, yielding highlyconserved HSPs for their protection from damage caused by heat stress (Locke and Noble, 1995). However, previous reports on cellular mechanisms during long-term thermal conditions are contradictory and require further clarification.

In the present study, liver, heat stress increased the liver mRNA expressions of HSP60, HSP70, and HSP90 genes. Earlier studies reported higher expressions of HSP70 and HSP90 genes after heat stress. In broilers, acute heat stress enhanced HSP70 activation in the liver, the heart, the kidneys, and the lungs (Sun et al., 2007; Yu, 2009) and HSP90 in the liver and the heart (Lei et al., 2009; Yu et al., 2008). In a study with ducks, HSP90 gene expression was increased in the liver by acute but limited heat stress after chronic heat stress (Wang et al., 2013). However, lower HSP gene expressions were determined in the liver and muscle tissues of the taurine-supplemented group submitted to heat stress. Xie et al. (2014) reported that acute and chronic types of heat stress increased protein oxidation, but HSP gene expressions remained unaltered in muscles. Chen et al.(2014) demonstrated that HSP70 gene expression is tissue-dependent, with the highest expression determined in the muscles, followed by the liver and the heart during cold stress. In heat-stress chickens, HSP expression is also tissuedependent (Gan et al., 2013; Leandro et al., 2004; Rajkumar et al., 2017; Zhen et al., 2006), as found in the present study, where liver tissues are more responsive than muscle tissues. Blake et al. (1990) stated that different tissues respond differently to heat stress, which corroborates our own findings. Nakai \& Morimoto (1993) argue that tissue-dependent responses may be related to differences in the heatshock-factor levels and that HSFs are responsible for the activation of heat shock elements under stress conditions (Mizuno et al., 1997).

Taurine osmoregulatory activity appears to be an important determinant of cell survival. During heat stress, the birds' body cells are subjected to osmotic stress. During hyperthermia, such as exposure to 
high ambient temperatures (heat stress), taurine and GABA may down regulate body temperature. Cells do not tolerate extreme variations in their sizes, which is why they possess volume-regulatory mechanisms to counteract the consequences of osmotic stress and to normalize their volumes. In most cell types, changes in taurine uptake and release contribute to the standardization of cell volumes. In the heart and the muscles, the taurine turnover is usually very slow. Yet, myocyte taurine content can be dramatically altered by changes in osmotic stress. However, there are still several unresolved issues regarding the role of taurine osmoregulatory actions in the muscles and the heart. Nonetheless, our present study and previous investigations demonstrate that the liver is the most and muscles are the least responsive to hightemperature challenges in HSP gene activation and protein expression, while taurine supplementation lowers both.

In conclusion, under heat stress, the synthesis of most proteins is delayed, but a group of highly-conserved proteins (heat shock proteins) is rapidly synthesized in broilers. The mRNA expressions of HSP90, HSP70, and HSP60 in liver and muscle tissues of broilers increased during heat exposure, as well as the expression of their proteins in the liver. The exposure of broilers to high temperature had negative effects but taurine supplementation improved their heat tolerance, as evidenced by the higher final body weights and reduced expressions of HSP genes and their protein expressions. The effect of taurine supplementation on the expression of HSPs was not evaluated in broilers maintained at thermal neutral conditions in the present experiment. Additionally, mRNA expressions of HSPs were tissue-dependent. The mRNA and protein expression levels of the evaluated HSPs were different in the liver and muscle tissues, which indicate that different organs respond differently to heat stress. This experiment suggests that taurine supplementation may be used in poultry industry to reduce heat stress. However, the mechanisms and the extension of taurine protection of HSPs in broilers are not fully known and require further research.

\section{ACKNOWLEDGEMENTS}

This work was supported by the Basic Science Research Program, through the National Research Foundation of Korea (NRF) funded by Ministry of Education (Project No. NRF2017R1D1A3B03028490).

\section{REFERENCES}

Arrigo AP. HSPs as novel regulators of programmed cell death and tumorigenicity. Pathologie Biologie Resource 2000;48:280-288.

Benjamin I, Mcmillan RD. Stress (Heat shock) proteins: molecular chaperones in cardiovascular biology and disease. Circulation Research 1998;83:117-132

Blake MJ, Gershon D, Fargonli J,Holbrook NJ. Discordant expression of heat shock proteins mRNAs in tissue of heat-stressed rats. The Journal of Biological Chemistry 1990;265:15275-15279.

Bukau B, Deuerlin E, Pfund C, Craig EA. Getting newly synthesized proteins into shape. Cell 2000;101(2):119-122.

Chen $X Y$, Juan, JN, Run SJ, Zhao YG. Expression profile of heat shock protein 70 in indigenous huainan partridge chicken exposed to low temperature. Italian Journal of Animal Science 2014;13:235-238.

Deeb N, Cahaner A. Genotype-by-environment interaction with broiler genotypes differing in growth rate. 3. Growth rate and water consumption of broiler progeny from weight-selected versus nonselected parents under normal and high ambient temperatures. Poultry Science 2002;81:293-301

Deyhim F, Stoecker BS, Adeleye BG, Teeter RG. The effects of heat distress environment, vitamin, and trace mineral supplementation on performance, blood constituents, and tissue mineral concentrations in broiler chickens. Nutrition Research 1995;15:521-526.

Felver-Gant J, Mack L, Dennis R, Eicher S, Cheng HW. Genetic variations alter physiological responses following heat stress in 2 strains of laying hens. Poultry Science 2012;91:1542-1551.

Gan JK, Zhang DX, He DL, Zhang XQ, Chen ZY, Luo QB. Promoter methylation negatively correlated with mRNA expression but not tissue differential expression after heat stress. Genetics and Molecular Research 2013;12(1):809-812.

Habich C, Burkart V. Heat shock protein 60: regulatory role on innate immune cells. Cellular and Molecular Life Sciences 2007;64:742-751.

Ipek A, Canbolat O, Karabulut A. The effect of vitamin E and vitamin C on the performance of japanese quails (Coturnix Coturnix Japonica) reared under heat stress during growth and egg production period. Asian Australasian Journal of Animal Science 2007;20:252-256.

Ito T, Fujio Y, Hirata M, Takatani T, Matsuda T, Muraoka S, et al. Expression of taurine transporter is regulated through the TonE (tonicity-responsive element)/TonEBP (TonE-binding protein) pathway and contributes to cytoprotection in HepG2 cells. Biochemical Journal 2004;382(1):177182.

King YT, Lin CS, Lin JH, Lee WC. Whole-body hyperthermia-induced thermotolerance is associated with the induction of heat shock protein 70 in mice. Journal of Experimental Biology 2002;205:273-278.

Kocak-Toker N, Giris M, Tulubas F, Uysal M, Aykac-Toker G. Peroxynitrite induced decrease in $\mathrm{Na}^{+}, \mathrm{K}^{+}$-ATPase activity is restored by taurine. World Journal of Gastroenterology 2005;11:3554-3557.

Krebs RA, Bettencourt BR. Heat shock protein variation and the evolution of thermotolerance in Drosophila. American Zoologist 1999;39(6):910919.

Leandro NS, Gonzales E, Ferro JA, Ferro ML, Givisiez PE, Macari M. Expression of heat shock proteins in broiler embryo tissues after acute cold or heat stress. Molecular Reproduction and Development 2004;67:172-177. 
Lei L, Yu J, Bao E. Expression of heat shock protein 90 (Hsp90) and transcription of its corresponding mRNA in broilers exposed to high temperature. British Poultry Science 2009;50:504-511.

Locke M, Noble EG. Stress protein. 1. The exercise response. Canadian Journal of Applied Physiology 1995;20:155-167.

Maloyan A, Palmon A, Horwitz M. Heat acclimation increase the basal HSP72 level and alters its production dynamics during heat stress. American Journal of Physiology- Regulatory, Integrative and Comparative Physiology 1999;276:R1505-R1515.

Mashaly M, Hendricks GL, Kalama MA, Gehad AE, Abbas AO, Patterson PH. Effect of heat stress on production parameters and immune response of commercial laying hens. Poultry Science 2004;83:889-894.

Mizuno S, Ishii A, Murakami Y, Akagawa H. Stress dose dependent suppression of heat shock protein gene expression by inhibiting protein synthesis during heat shock treatment. Cell Structure and Function 1997;22:7-13

Morimoto RI. Regulation of the heat shock transcriptional response: cross talk between a family of heat shock factors, molecular chaperones, and negative regulators. Genes and Development 1998;12:3788-3796.

Nakai A, Morimoto RI. Characterization of a novel chicken heat shock transcription factor heat shock factor 3 suggests new regulatory pathway. Molecular and Cellular Biology 1993;13:1983-1997.

Plavnik I, Yahav S. Research notes: Effect of environmental temperature on broiler chickens subjected to growth restriction at an early age. Poultry Science 1998;77(6):870-872

Quinteiro-Filho WM, Ribeiro A, Ferraz-de-Paula V, Pinheiro ML, Sakai M, Sá LRM, et al. Heat stress impairs performance parameters, induces intestinal injury and decreases macrophage activity in broiler chickens. Poultry Science 2010;89:1905-1914.

Rajkumar U, Vinoth A, Shanmugam M, Rajaravindra KS, Rama Rao SV. Effect of increased incubation temperature on Hsp 90 and 60 gene expressions in coloured broiler chickens. Journal of Applied Animal Research 2017;45(1):298-303.

Rajkumar U, Reddy MR, Rama Rao SV, Radhika K, Shanmugam M. Evaluation of growth, carcass, immune response and stress parameters in naked neck chicken and their normal siblings under tropical winter and summer temperatures. Asian-Australasian Journal of Animal Science 2011;24:509-516.

Schaffer SW, Chian JJ, Ramila KC, Junichi A. Physiological roles of taurine in heart and muscle. Journal of Biomedical Science 2010;17(Suppl 1):S2.

Shim KS, Hwang KT, Son MW, Park GH. Lipid metabolism and peroxidation in broiler chickens under chronic heat stress. Asian-Australasian Journal of Animal Science 2006;19:1206-1211.

Sohail M, Hume M, Byrd J, Nisbet D, ljaz A, Sohail A, et al. Effect of supplementation of prebiotic mannan-oligosaccharides and probiotic mixture on growth performance of broilers subjected to chronic heat stress. Poultry Science 2012;91:2235-2240.
Staib JC, Quindry JC, French JP, Criswell DS, Powers SK. Increased temperature, not cardiac load, activates heat shock transcription factor 1 and heat shock protein 72 expression in the heart. American Journal of Physiology- Regulatory, Integrative and Comparative Physiology 2007;292:432-439

Sun PM, Liu YT, Wang QH, Wang ZL, Bao ED. Localizations of HSP70 and HSP70 mRNA in the tissues of heat stressed broilers. Journal of Agricultural Biotechnology 2007;15:404-408.

Vinoth A, Thirunalasundari T, Tharian JA, Shanmugam M, Rajkumar U. Effect of thermal manipulation during embryogenesis on liver heat shock protein expression in chronic heat stressed colored broiler chickens. Journal of Thermal Biology 2015;53:162-171.

Wang DQ, Lu LZ, Tian Y, Li JJ, Shen JD. Cloning and expression of heat shock protein 90 (HSP90) cDNA sequence from shaoxing duck (Anas platyrhynchos). Journal of Agricultural Biotechnology 2013;21:55-61.

Wang S, Edens FW. Heat conditioning induces heat shock proteins in broiler chickens and turkey poults. Poultry Science1998;77:1636-1645.

Xie J, Tang L, Lu L, Zhang L, Xi L. differential expression of heat shock transcription factors and heat shock proteins after acute and chronic heat stress in laying chickens (Gallus gallus). PLoS ONE2014;9(7):1-9.

Yahav S, Shamay A, Horev G, Bar-ilan D, Genina O, Friedman-einat M. Effect of acquisition of improved thermotolerance on the induction of heat shock proteins in broiler chickens. Poultry Science 1997;76:14281434.

Yu J. The mechanism of heat shock protein expressions and tissue damage in heat stressed broilers [dissertation]. Naquin (CHN): Nanjing Agricultural University; 2009. p.133.

Yu J, Bao E, Yan J, Lei L. Expression and localization of Hsps in the heart and blood vessel of heat-stressed broilers. Cell Stress \& Chaperones 2008;13:327-335

Zhen FS, Du HL, Xu HP, Luo QB. Tissue and allele specific expression of hsp 70 gene in chicken basal and heat stress-induced mRNA level quantified with real-time reverse transcriptase polymerase chain reaction. British Poultry Science 2006;47:449-455.

Zügel U, Kaufmann SHE. Role of heat shock proteins in protection from and pathogenesis of infectious diseases. Clinical Microbiology Reviews 1999;12:19-39.

Zulkifli I, Htin NN, Alimon AR, Loh TC, Hair- Bejo M. Dietary selection of fat by heat-stressed broiler chickens. Asian-Australasian Journal of Animal Science 2007:20:245-251.

Zulkifli I, Mysahra SA, Jin LZ. Dietary supplementation of Betaine (Betafin) and response to high temperature stress in male broiler chickens. Asian-Australasian Journal of Animal Science 2004;17:244-249. 
